\title{
NIGERIAN NATIONAL COUNCIL ON PUBLIC PROCUREMENT: ADDRESSING THE UNRESOLVED LEGAL ISSUES
}

\author{
Kingsley Tochi Udeh
}

\section{(2015) 2 APPLJ 1}

\begin{abstract}
The National Council on Public Procurement (NCPP) is one of Nigeria's two federal procurement regulatory authorities established by the Public Procurement Act 2007. More than seven years after the statutory establishment of the NCPP, the body is yet to be constituted; consequently, there is no proper performance of its statutory functions. This has continued to generate debate in several quarters. In response, the Federal Government has advanced various reasons for not constituting the body, which are mostly based on misconceptions about the status and functions of the body. Nonetheless, the non-constitution of the Council still has implications for Nigerian public procurement system. This article examines NCPP's status and functions, critiques identified misconceptions about the body, analyses the implications of not constituting the regulatory body, and assesses the benefits of constituting it.
\end{abstract}




\section{NIGERIAN NATIONAL COUNCIL ON PUBLIC PROCUREMENT: ADDRESSING THE UNRESOLVED LEGAL ISSUES}

Kingsley Tochi Udeh

LL.B, BL, LLM.

Lecturer in Law, Baze University Abuja-Nigeria; Consulting Partner: T.K Udeh \& Associates (Legal Practitioners \& Consultants); Member, African Public Procurement Regulation Research Unit, Stellenbosch University.

\section{Introduction}

A country's public procurement system operates through institutions and management structures, including regulatory bodies. The National Council on Public Procurement (NCPP or Council) is one of Nigeria's two federal procurement regulatory authorities established by the Public Procurement Act 2007 (PPA or Act). More than seven years after the statutory establishment of the NCPP, the body is yet to be constituted; consequently, there is no proper performance of its statutory functions. This has continued to generate debate in several quarters, including the National Assembly (Nigeria's federal legislature), ${ }^{1}$ academic literature, ${ }^{2}$ and civil society organisations. ${ }^{3}$ Various reasons mostly based on misconceptions about the status and functions of the body, seen in section 4 below, have been advanced by the Federal Government for not constituting the NCPP. Recently however, the Federal High Court in Cupero Nigeria Limited $v$ Federal Ministry of Water Resources ${ }^{4}$ rejected the argument that the NCPP does not exist by virtue of its nonconstitution. Nonetheless, the non-constitution of the Council still has implications for Nigerian public procurement system.

This article shall examine NCPP's status and functions, critique identified misconceptions about the body, analyse the implications of not constituting the regulatory body, and assess the benefits of constituting it. The theme is topical for three reasons. First is the critical statutory role that the NCPP is intended to play in

\footnotetext{
${ }^{1}$ Nigerian Senate, 2012. Order Paper (No 139). Abuja: National Assembly, 333-334. Procurement Monitor, 2011.

2 Udeh \& Ahmadu 2013:149; Williams-Elegbe 2012:348; Osuntogun 2012:149-150.

${ }^{3}$ See Dailyindependent, 2014; Newsdiaryonline, 2011; and, Akalugo, 2011.

${ }^{4}$ FHC Abuja 12-6-2012 suit no FHC/Abj/CS/867/11, 61.
} 
Nigeria's procurement system and by extension its economy, currently estimated to be the largest in Africa. ${ }^{5}$ Second, is that the related issues are still largely unsettled. ${ }^{6}$ Third, is that a new administration was sworn in on $29^{\text {th }}$ May 2015; thus there may be a reconsideration of the stance of the Federal Government on the constitution of the NCPP. Even when the NCPP is hopefully constituted, the issues addressed here will still be topical since they are germane to understanding and delimiting the powers and operations of the Council.

Before addressing the issues raised above, it is apposite to briefly consider the historical background to the establishment of the Council, as it will enhance appreciation of the issues.

\section{Historical background}

There was no statutory regulation of public procurement in Nigeria until $4^{\text {th }}$ July 2007. ${ }^{7}$ During the period, extant Financial Regulations (FR) issued by the Minister of Finance, ${ }^{8}$ stipulated the composition and award limits of contract-awarding authorities (such as Tender Boards) for each government entity. But, it neither prescribed tender procedures nor created procurement regulatory functions. ${ }^{9}$ Thus, there was no independent body exercising oversight on public procurement practices; except that the Minister undertook routine finance management control to ensure fiscal discipline in public expenditure. ${ }^{10}$ In addition, there was no formal mechanism to involve or encourage citizens and civil society organizations (CSOs) in undertaking social accountability or audit of public procurement. ${ }^{11}$ Social accountability refers to the broad range of actions and mechanisms beyond voting that citizens can use to help the government to be more effective and

\footnotetext{
${ }^{5}$ It has an estimated nominal GDP of USD 510 billion. See AfDB, OECD \& UNDP, 2014:2. The Economist, 2014. BBC, 2014.

${ }^{6}$ Academic work, such as Udeh \& Ahmadu 2013:149; Williams-Elegbe 2012:348; Osuntogun 2012:149-150, have drawn attention to the non-constitution of the NCPP, but has scarcely addressed the related issues, since these issues were not the focus of the work.

${ }^{7}$ The date the PPA was enacted.

${ }^{8}$ Pursuant to Finance (Control and Management) Act 1958 Cap F26 LFN 2004 s 4. The FR was a set of internal rules on financial control of the Federal administration. They were supplemented by internal circulars and guidelines issued by certain authorized officers.

${ }^{9}$ For example, there was no rule on bid advertisement, procurement methods, bid evaluation criteria, etc. World Bank, 2000:7.

${ }_{11}^{10}$ Finance (Control and Management) Act s 3.

${ }^{11}$ On the significance of social accountability or audit to public procurement systems, see: OECD-

DAC/World Bank, 2006:44-45.
} 
accountable. $^{12}$ Another weakness of the procurement system then was that government contracting authorities, within their award limits, had liberty to award to any contractor of their choice; which undermined competition and also the enforcement role that would have been played by bidders through challenge proceedings. ${ }^{13}$ Nigerian administrative law had then not developed to recognise the right of bidders to challenge award decisions of government entities based on procedural unfairness, unreasonableness, etc. ${ }^{14}$ Bidders then could only challenge awards based on very limited contract law principles; such as the rule in Harvela Investments Ltd $v$ Royal Trust of Canada; ${ }^{15}$ that recognises the right to enforce where invitation to tender states that award shall be to the lowest bidder. The above situation was the same in the states. ${ }^{16}$

As a result, the system was easy to manipulate, difficult to control and not transparent to bidders and the public. ${ }^{17}$ Government did not get value for money and was not perceived by the private sector as a reliable business partner. ${ }^{18} \mathrm{~A}$ team of the World Bank and Nigerian Government officials/consultants constituted in 1999 to conduct Nigeria's Country Procurement Assessment, having identified the above weaknesses among others, recommended that a public procurement law based on the United Nations Commission for International Trade Law (UNCITRAL) model ${ }^{19}$ be enacted. ${ }^{20}$ It also recommended that a procurement regulatory body be established for policy making and ensuring compliance with the procurement law. ${ }^{21}$ In response, the PPA was enacted in 2007, which established two regulatory bodies: the NCPP and the Bureau of Public Procurement (BPP). ${ }^{22}$ The BPP, which is vested with the core procurement regulatory functions, ${ }^{23}$ is largely fully functional. Nonetheless, the

\footnotetext{
${ }^{12}$ World Bank, 2005:5.

${ }^{13}$ On the procurement law enforcement role of suppliers, see Zhang 2007:325 327; Quinot 2013:308; Marshall et al 1991:20-23; Arrowsmith 1992:93.

${ }^{14}$ See CBN v System Application Products Nigeria Limited (2005) 3 NWLR (Pt. 911) 152.

${ }^{15}$ (Cl) Ltd [1986] AC 207.

${ }^{16}$ Nigeria is a federation, currently of 36 states. The states have their autonomous procurement systems, most of the time patterned after that of the Federal Government.

${ }^{11}$ World Bank, 2000:8.

${ }^{18}$ World Bank, 2000:8.

${ }^{19}$ The UNCITRAL Model Law on Procurement of Goods, Construction and Services 1994. The current version of the Model Law is the UNCITRAL Model Law on Public Procurement 2011.

${ }^{20}$ World Bank, 2000:6. See also Williams-Elegbe 2012:340-346.

${ }^{21}$ World Bank, 2000:8.

${ }^{22}$ Sections 1 and 3 respectively.

${ }^{23}$ Include: formulating procurement policies; supervising the policy implementation; conducting procurement trainings and awareness; certifying certain Federal procurement prior to the award of contract; preparing and updating standard bidding and contract documents; preventing fraudulent and
} 
status and functions of the NCPP, which have been left inchoate, are not less important, as seen immediately below.

\section{Status and functions of NCPP}

\section{Status}

The PPA prescribes that the NCPP shall consist of 12 members, ${ }^{24}$ appointed by the Nigerian President; ${ }^{25}$ out of which six permanent members shall be specified government officials. They include: the Minister of Finance as Chairman; the Director General of BPP, as the Secretary; and the Attorney-General of the federation, the Secretary to the Government of the Federation, the Head of Service of the Federation, and the Economic Adviser to the President. The other six, referred to by the PPA as part-time members, are representatives of specified CSOs. These include: the Nigerian Bar Association; the Nigerian Institute of Purchasing and Supply Management; Nigeria Association of Chambers of Commerce, Industry, Mines and Agriculture; Nigeria Society of Engineers; and Civil Society (contextually refers to nongovernmental organizations) and the media. Here and as widely accepted, CSOs refer to the set of institutions and organisations that inter-phase between the state, business world, and the family; and broadly include: nongovernmental organizations (NGOs), private voluntary organizations (PVOs), peoples' organizations, community-based organizations (CBOs), civic clubs, trade unions, gender groups, cultural and religious groups, charities, social and sports clubs, cooperatives, environmental groups, professional associations, academia, policy institutions, consumer organizations, and the media. ${ }^{26}$

The CSOs' representatives are intended to play a decisive role in the NCPP, considering that the Council's decision is by voting. ${ }^{27}$ However, the PPA does not prescribe the procedures for voting. If the Nigerian parliamentary practice that restrains a presiding officer from voting, except for casting votes in event of a tie ${ }^{28}$ is

\footnotetext{
unfair procurement and where necessary apply administrative sanctions; performing procurement audits; maintaining database of public procurement information; entertaining procurement complaints; etc. See PPA ss 5, 6, 53 and 54.

${ }^{24}$ Section $1(2)$.

${ }^{25}$ Section 1(4).

${ }^{26}$ Essia \& Yearoo 2009:368-369. See also Ikelegbe 2013:5-6.

${ }^{27}$ Section $1(3)$.

${ }^{28}$ Constitution of the Federal Republic of Nigeria 1999 (“CFRN") ss 56 (1) \& 98(1).
} 
adopted, it will vest majority deliberative votes on the CSO-members and will further enhance their potential influence in the Council. But as explained in 413 below, it is most unlikely that this practice would be adopted.

From the foregoing, the NCPP could be regarded as partly a formal mechanism to involve CSOs towards enhancing integrity and accountability in public procurement, as would be seen in in 412 and 6 below. Unfortunately, one of the reasons why the Federal Government has not constituted the NCPP is its concerns about the composition, discussed under 413 below. As hinted in the introduction, although the Council is not yet constituted, it is regarded as an existing statutory body. The implication of this is discussed under 411 below.

\section{Functions}

The functions of the NCPP establish it as an approval authority, and to an extent as a regulatory authority, over the BPP. These functions are here broadly classified as its "core functions" and "other functions". Its core functions are those specifically provided in section 2 (entitled "Functions of the Council"), under part 1 of the PPA (which deals exclusively with the NCPP). The "other functions" are those that are provided at various other parts of the PPA (which may be unnoticed on a cursory look). This classification is necessary because it has been observed that many academic discourses and publications on the functions or powers of the NCPP focus on those under part $1 .^{29}$ Thus, this classification will draw needed attention to the other functions of the Council.

\section{Core functions}

The following are the core functions of the NCPP: ${ }^{30}$

(a) Considering, approving and amending the monetary and prior review thresholds for the application of the provisions of the PPA by procuring entities;

\footnotetext{
${ }^{29}$ See for example Osuntogun 2012:145-146; however, approval of code of conduct was mentioned in 152. See also Onyekpere, 2013; Citizen Confidential, 2012; and Akalugo, 2011.

${ }^{30}$ PPA, s 2.
} 
(b) Considering and approving policies and guidelines/regulations on public procurement; ${ }^{31}$

(c) Approving the appointment of the Directors of the BPP;

(d) Receiving and considering for approval the audited accounts of the BPP, ${ }^{32}$

(e) Approving changes in the procurement process to adapt to improvements in modern technology; and

(f) Giving such other directives and performing such other functions as may be necessary to achieve the objectives of the PPA.

Monetary and prior review thresholds mentioned in function (a) respectively refer to: the value limit in Naira set by the Bureau/NCPP outside of which an approving authority may not award a procurement contract; ${ }^{33}$ and the value limit of contracts that require BPP's "certificate of no objection" before the award of such contracts. ${ }^{34}$ For monetary thresholds, the higher the value of contract the higher the level of authority that can award it; also, more number of persons or offices are required to constitute the approving authority for higher value contracts. ${ }^{35}$ In the same vein, it is high-value contracts ${ }^{36}$ that are subject to BPP's prior review or no objection certification. The importance of setting these thresholds is that they are used to ensure stricter control or scrutiny in the award of high-value contracts; to reduce chances of corruption or mismanagement, which will result in higher economic loss than in low-value contracts. Some monetary and prior review thresholds are set by

\footnotetext{
${ }^{31}$ See also ss $5($ a) and 18.

${ }^{32}$ See also s 13(5).

${ }^{33}$ Section 60: "Monetary threshold". The NCPP is added in the above definition of monetary threshold because $s 0$ is considered together with other relevant sections relating to setting of monetary thresholds, as would be discussed under this subheading. "Approval authorities" refer to various persons or group of persons that have powers to award contracts (that fall within their award limits) for their respective organizations.

${ }^{34}$ Sections 7(1), 16(1)-(4).

${ }^{35}$ For example, Permanent Secretaries (accounting officers) of Federal ministries have powers to award goods and services contracts of below N 5 million, and works contracts of below N 10 million; whereas the Ministerial Tenders Board (usually composed of the Permanent Secretary, as Chairman, and the Directors heading various departments in the Ministry) awards goods and services contracts of $\mathrm{N} 5$ million to less than $\mathrm{N} 100$ million, and works contract of $\mathrm{N} 10$ million to less than $\mathrm{N} 1.0$ billion; the Federal Executive Council (composed of the President, the vice-President and all ministers) is the approving authority for goods and services contracts of $\mathrm{N} 100$ million and above, and works contracts of over N 1.0 billion. See FGN, 2009:3.

${ }^{36}$ Goods and services contracts of $\mathrm{N} 100$ million and above, and works contracts of over N 1.0 billion. See FGN, 2009:3.
} 
the BPP, ${ }^{37}$ but subject to the approval or amendment of the NCPP. The current thresholds were approved by the Federal Executive Council (FEC), ${ }^{38}$ instead of the NCPP, contrary to the law. The FEC is "the body of Ministers of the Government of the Federation, howsoever called, established by the President and charged with such responsibilities for the functions of government as the President may direct". ${ }^{39}$ It is chaired by the President, or, in his absence, his Vice.

According to some provisions of the Act, the NCPP may generally set these thresholds. ${ }^{40}$ The interpretation may be that the NCPP will do so by amending the thresholds set and presented for approval by the Bureau; or that it has powers to set thresholds on matters which the BPP is not specifically empowered to set thresholds on. This is reasonable considering that section 5(c) (on BPP's functions), stipulates that the BPP shall certify procurements subject to thresholds as may be set by the NCPP; and section 6(1)(a) (on BPP's powers) states that the BPP shall "enforce the monetary and prior review thresholds set by the Council". As these indicate, setting of thresholds by BPP is not mentioned under the functions or powers of BPP. In addition, where the Act stated that the BPP may set thresholds, it specifically identified the procurement matters involved; it conversely did not identify specific matters where it stated that NCPP may set thresholds. ${ }^{41}$

On function (b) above, the BPP formulates public procurement policies and regulations; ${ }^{42}$ but again it is subject to the approval of the NCPP. The membership of the NCPP, especially considering its CSOs membership, puts the Council in a good stead to act as a moderator of procurement policies formulated by BPP, towards balancing the interests of Government, the business community and the general public. Functions (c) to (e) clearly indicate that NCPP's approvals are statutory preconditions for the actions of the other authorities mentioned to be valid. Functions

\footnotetext{
${ }^{37}$ Sections 25(1); 26(1), (on use of either National or International Competitive Bidding), 16(1)-(4), and 60: "Monetary threshold".

${ }^{38}$ FGN, 2009:1.

${ }^{39}$ CFRN s 144(5), where it is referred to as "the Executive Council of the Federation".

${ }^{40}$ Sections 5(c); 6(1)(a); 17.

${ }^{41}$ Nonetheless, it could be conceded that the drafting of the provisions on setting and approving of monetary and review thresholds may lead to ambiguity. One may use this opportunity to draw attention to a drafting/typographic error in the Act, viz.: s 16(1) (relates to monetary and review threshold) referred to a non-existent s 7(1)(a)-(b), instead of 6(1)(a)-(b).

${ }^{42}$ PPA ss 4(a), 5(a), 16(22), and 18.
} 
(f) is an omnibus clause; yet it is limited and incidental to carrying out the specified functions of the Council, as would be discussed in 423 below.

\section{Other functions}

In addition to the above core functions of the Council, the following are some of its other functions:

- Approval of BPP's decision to enter into partnership or liaison with any entity towards discharging its functions, and to obtain relevant information/documentation from procuring entities; ${ }^{43}$

- Recommending to the President the appointment of the Director-General of the BPP; 44

- Appointment of BPP's principal officers and other employees; ${ }^{45}$

- Making staff regulations on the terms and conditions of service of BPP's employees; ${ }^{46}$

- When necessary, modify BPP's operational structure to enhance the Bureau's duties and functions; $; 7$

- Approving the establishment and maintenance of a fund by the BPP, and making regulations for its operation, and prescribing how an annual statement of account shall be prepared by BPP; 48

- Receiving from BPP a report of its activities for the preceding year, and its budget for the succeeding year; ${ }^{49}$

\footnotetext{
${ }^{43}$ Section 6(3). The requirement for NCPP's approval for BPP to obtain information/documentation from procuring entities may be rendered unnecessary by section 1(1) of the more recent Freedom of Information Act 2011.

${ }^{44}$ Section $7(1)$.

${ }^{45}$ Sections 8(1) and 9(1)\&(3).

${ }^{46}$ Sections 9(2) and 10(1); this covers remuneration, promotion, disciplinary control, etc.

${ }^{47}$ Section 8(3).

${ }^{48}$ Sections $12(1) \&(3), 13(3)$.

${ }^{49}$ Section 13 (5) \& (2) respectively. The second limb of the function suggests that the Council shall be responsible for submitting BPP's annual budget estimate to the FEC to consider for incorporation into the annual budget of the Federal Government, for subsequent presentation to the National Assembly. The chairmanship of the Council by the Minister of Finance, who is responsible for collating budget
} 
- Approving guidelines made by the BPP on the membership of the Tenders Boards $;^{50}$

- Approving guidelines, policies and practices made by the BPP on disposal of public property $;{ }^{51}$

- Approving a code of conduct stipulated by the BPP for all persons involved in public procurement and disposal, and oath of office for officers involved in public procurement. ${ }^{52}$

The above further indicate the significance of NCPP to Nigeria's public procurement and disposal system; for the Council generally is intended to act as a check on certain administrative and regulatory functions of the BPP. ${ }^{53}$ Thus, it will keep the main regulatory body also accountable.

Notwithstanding that the NCPP is neither constituted nor functioning, the BPP has, since its inception, prescribed thresholds and procurement policies and regulations; also, BPP's Director-General, Directors, principle officers and other employees have been appointed since 2007; furthermore, BPP has been running its accounts; and changes have been made to procurement process to adapt technology, e.g. introduction of procurement plan software by BPP. The question is, to what extent are these actions valid or sustainable? This is discussed in section 5 below.

However, it is apposite at this juncture to consider the misconceptions about the NCPP, which have contributed to the government's reluctance to constitute the body. Interestingly, some views expressed to persuade the Government to constitute the NCPP have added to the misconceptions or confusion, further strengthening the Federal Government's reluctance to constitute the Council, as would be seen in 42 1 below.

estimates of Federal agencies, supports this supposition. See Fiscal Responsibility Act 2007, ss 21 and 56 ("Minister").

${ }^{50}$ Section 22(2).

${ }^{51}$ Section 55(4).

${ }^{52}$ Section 57(1) \& (3).

${ }^{53}$ Discussed further in 1423. 


\section{$4 \quad$ Misconceptions}

The misconceptions about the NCPP generally relate to its status and functions. The misconceptions are therefore critiqued under those broad aspects.

\section{About its status}

\section{Not established or non-existent}

Since the Council is neither constituted nor performing its functions, it has been regarded that the body does not exist or is not established. ${ }^{54}$ However, according to the court in Cupero case,$^{55}$ although the NCPP is yet to be constituted, it is a misconception to opine that it is non-existent or not established. This view is correct, as section 1(1) of PPA states that: "there is established the National Council on Public Procurement". One may be wondering whether holding that the Council is not constituted and that it is not established are not practically of the same effect. They are not. Holding that the NCPP is not established implies that there are currently two unmet preconditions stalling the commencement of NCPP's functions: first, is establishing the body; second, is to constitute it. To appreciate this point, one need to note that there are instances where a statute may not establish a body, but only directs that the body be established in the future or when required. ${ }^{56}$ Meaning that in such instance, the body would have to first be established (usually by legislation or by other valid means) before it could be constituted. On the contrary, in the case of NCPP, it is only constituting or inaugurating the membership of the already established body that is currently required. ${ }^{57}$

\footnotetext{
${ }^{54}$ See for example Osuntogun 2012:149, 151-152. See also the argument of Counsel to $1^{\text {st }}$ defendant in Cupero Nigeria Limited v Federal Ministry of Water Resources FHC Abuja 12-6-2012 suit no $\mathrm{FHC/Abj/CS/867/11.}$

${ }^{55}$ Cupero Nigeria Limited v Federal Ministry of Water Resources FHC Abuja 12-6-2012 suit no $\mathrm{FHC/Abj/CS/867/1161.}$

${ }^{56}$ See for example CFRN 1999 s 6(4), which does not establish inferior courts but empowers the federal or state governments that require them to do so by legislation.

${ }^{57}$ The distinction between establishing a body and constituting its membership could be inferred in these Nigeria's Court of Appeal decisions: Braithwaite $v$ Grassroots Democratic Movement (1998) 7 NWLR (Pt 557) 307; Alliance for Democracy (AD) v Plateau State Independent Electoral Commission [2004] 10 NWLR [Pt 880] 19.
} 
This is similar to what obtains under several pieces of Nigerian federal legislation, ${ }^{58}$ which usually establish the governing board or council of an agency or institution and then vests the President (or other authorities) with the power to appoint or constitute the membership of the board or council. ${ }^{59}$ The establishment by law immediately confers such a board or council with a legal personality (to sue and be sued in its corporate name, etc.); but it only begins to actually function when the membership is properly appointed or constituted, and it forms the requisite quorum for its meetings. ${ }^{60}$

\section{Deemed as constituted}

Since the Federal Government has, through other agencies, been performing some of the functions of the NCPP, it is probable that it deems the body as constituted, as the designated full-time members of the Council are all current Federal office holders. However, the NCPP cannot be deemed as constituted as such, for three reasons.

First, according to the Act, the Nigerian President must have to specifically appoint all the members to serve in that capacity. ${ }^{61}$ Thus, notwithstanding that the designated permanent members are public officers, they cannot be said to be performing the functions of the Council unless the President formally appoints them for that purpose.

Secondly, meetings of the Council shall be by quorum, ${ }^{62}$ and as pointed out in 31 above, decision is by voting of members. The PPA does not indicate the number of members that shall constitute a quorum; thus one would have to be guided by the Interpretation Act. ${ }^{63}$ According to the Interpretation Act, ${ }^{64}$ it has to be (at least) a

\footnotetext{
${ }^{58}$ See for example, Infrastructure Concession Regulatory Commission (Establishment, etc) Act 2005 s 15; Federal Inland Revenue Service (Establishment) Act 2007 s 3; Legal Education (Consolidation, etc) Act Cap L10 LFN 2004, ss 2 \& 3; Public Enterprises (Privatisation and Commercialisation) Act 1999 s 9; National Environmental Standards and Regulations Enforcement Agency (Establishment) Act 2007 s 3.

${ }^{59}$ Membership of these bodies includes ex-officio members, who in most cases are appointed by the

President to the offices that qualify them to be ex-officio members of the body.

${ }^{60}$ See provisions of legislation referred to in fn 58 above.

${ }^{61}$ PPA S 1(4).

62 PPA, 51 (3).

${ }^{63}$ CAP I23 LFN 2004.
} 
majority of the members; which the permanent members alone cannot constitute. In other words, the Council requires its part-time (CSO) membership to form a quorum. It is only when a quorum is formed that the Council can vote or perform its functions. This is not obviated by section 59(4) of the PPA that provides that the validity of any proceeding of the Council shall not be adversely affected by any vacancy in its membership: for a quorum must be formed before such vacancy can become immaterial.

Thirdly, apart from the necessity of forming a quorum, the Council cannot be complete without its CSO membership; for the intendment of the Act is to establish a public procurement system driven by public-private sector partnership. As noted by the OECD/World Bank MAPS, this partnership is critical to the functionality of the public procurement market. ${ }^{65}$

If it becomes accepted that the NCPP is deemed as constituted, this will prevent the Federal Government from properly constituting the body (considering its stance on it); which will deny the system of the intended benefits of establishing the body, discussed in 413 and 6 below.

\section{Concerns about part-time members}

As hinted in 413 above, one of the reasons disclosed by the Federal Government for not constituting the NCPP is its concerns about the loyalty and role of the parttime or CSO membership of the Council; which is apparently as a result of a misconception about the requirements of the law on their appointment and power (voting strength). ${ }^{66}$ There is a view that the designated CSO-members shall be appointed by the President, in consultation with or as nominated or recommended by the respective CSOs that the PPA indicates shall be represented in the Council. ${ }^{67}$ It may be advisable for the President to work according to this view, to secure the institutional support and participation of these CSOs. However, the President reserves the right to appoint these members without consulting or getting

\footnotetext{
${ }^{64}$ Section 27(1)(a) "Where a body established by an enactment comprises three or more persons, then any act which the body is authorised or required to do may be done in the name of the body by a majority of those persons or of a quorum of them". 6532.

${ }^{66}$ See Citizen Confidential, 2012: where the related statement of the former Special Adviser to the former President on Media and Publicity, Dr Rueben Abati, was quoted. See also Thisdaylive, 2012.

${ }^{67}$ See Attah, 2012. Also deduced from author's interaction with some CSOs.
} 
recommendations from the CSOs; for the Act did not attach any condition to the exercise of the President's power to appoint the members. ${ }^{68}$ The only requirement that may be inferred from the provision that the part-time members shall represent the CSOs mentioned is that such members shall be appointed from the respective organisations. For example, any lawyer that is called to the Nigerian Bar, who pays his annual bar practising fees (thus, is a member of the Nigerian Bar AssociationNBA) can be appointed by the President to represent the NBA. ${ }^{69}$ Thus, the President can appoint from these organisations, without much ado, those he feels would not sacrifice their appropriate loyalty to the government and people of Nigeria on the altar of their organisations' interest or agenda. Moreover, the President can remove any of the members appointed; ${ }^{70}$ which can be employed to check sabotage of public interest amongst members.

Another concern about the CSO membership is that they may vote against and therefore delay the adoption of procurement policies favoured by the government. This concern is valid but misconceived, considering that the NCPP's permanent (public-officer) members have more voting strength than the part-time members, by virtue of section 27(1)(b) of the Interpretation Act. It provides that in any vote taken at a meeting of a body, the person presiding when the vote is ordered shall have a casting vote, whether or not he also has a deliberative vote. Since the Council is made up of equal number of CSO and government membership, the casting vote of the Chairman (who is a government official), added to his deliberative vote, ${ }^{71}$ gives the government the opportunity to vote-in any policy it favours in the Council.

However, instead of worrying about the practically non-existent dangers of constituting the NCPP that has CSO membership, the Federal Government should be more concerned about leveraging on the contributions that the CSO membership will bring to the Council and by extension to the Nigerian procurement system. Recall

\footnotetext{
${ }^{68}$ See s 1 (4). In contrast, Kenya, which is another African country that adapted the UNCITRAL Model Law in drafting its own Public Procurement and Disposal Act 2005, has the Public Procurement Oversight Advisory Board (some of whose functions are similar to those of the NCPP) whose members, according to $\mathrm{s} 22$ of the Act, are to be first nominated by specified organisations, from where the Minister can appoint from.

${ }^{69}$ See Legal Practitioners Act CAP L11 LFN 2004 s 8(2) \& (3)(c). Other factors that the President may consider, such as expertise in public procurement law, years of professional experience, etc. are within the absolute prerogative of the President.

${ }_{71}^{70}$ Interpretation Act s 11(1)(b).

${ }^{71}$ Since the PPA did not restrict the Chairman to only casting vote, he can exercise deliberative vote.
} 
that among the members of the NCPP would be representatives of professional bodies, including the Nigerian Society of Engineers; the Nigerian Chambers of Commerce, Industry, Mines and Agriculture; the Nigerian Institute of Purchasing and Supply Management; which have expertise in various aspects of private and public sector procurement that would be brought to bear in undertaking the functions of the Council.

\section{About its functions}

\section{Approves contracts}

It has been argued that awarding or approving the award of government contracts by the FEC is usurpation of a duty statutorily assigned to the NCPP, ${ }^{72}$ as the PPA does not constitute the FEC as a contract approving authority. ${ }^{73}$ It has further been argued that FEC's involvement in awarding or approving award of contracts conflicts with CPAR's recommendation that "high level politicians (FEC members) should maintain their overall managerial oversight responsibilities while leaving administrative and operational matters to the civil servants". ${ }^{74}$

These arguments are highly contestable. First, according to the PPA, sections 2 and 17 , the NCPP is an approving authority for public procurement policies, not for award of contracts. In other words, it has no power or function to approve or award contracts; rather it approves general policies relating to procedures for award and administration of government contracts. Likewise, section 2(a) that vests the NCPP with power to "consider, approve and amend the monetary and prior review thresholds for the application of the provisions of this Act by procuring entities" is to the effect that the NCPP may by itself amend, or approve (when amended by the BPP): (1) the laid down monetary value (thresholds) of contracts that an approving authority can award; and, (2) the established value of contracts that may be subject

\footnotetext{
${ }^{72}$ Osuntogun 2012:149. A statement by Dr Abati (reported in Citizen Confidential, 2012) captured this misconception about the NCPP being a contract approving entity, thus: "But the law (PPA) now says the Council should approve anything...Can the Procurement Council approve one trillion Naira worth of contracts?". See also Attah , 2012.

${ }^{73}$ Contra: Osuntogun 2012:149, 151; Suleiman, 2013; Channels Television, 2012. Also Citizen Confidential, 2012, where FEC's approval of contract award was argued as "illegal and unfounded in law"; and Nigeriannewsservice, 2009.

${ }^{74}$ Citizen Confidential, 2012 (parenthesis added), quoting with modification World Bank, 2000:11.
} 
to prior review of the BPP. Thus, it only approves or lays down the contract award limits for the relevant authorities, but has no power to approve or award any contract.

Secondly, the FEC does not get involved in procurement administrative and operational process. Rather it awards or approves award of contracts that fall within stipulated monetary thresholds, ${ }^{75}$ after the procuring entities have concluded the procurement process and made recommendations on award. Thus, FEC's role here is a form of managerial oversight on public procurement; and is consistent with the CPAR recommendation.

Thirdly, if FEC chooses not to be involved in contract award or approvals it will be by virtue of its absolute discretion; not that it lacks the powers to do so. FEC is the highest decision-making executive organ recognized by the Constitution; ${ }^{76}$ and, its power to approve or award contracts was accorded judicial notice or recognition in Federal Republic of Nigeria v Olabode George. ${ }^{77}$

Fourthly, the PPA does not exclude the FEC from approving or awarding contracts. Even though the PPA only mentions the Parastatals Tender Board (PTB) and Ministerial Tender Board ("MTB") as contract approving authorities; reading the PPA as a whole indicates that the section does not constitute them as the exclusive contract approving authorities. They are contract approving authorities as far as the contracts fall within the threshold prescribed for them. For according to PPA, section 17, the PTB and MTB are approving authorities "subject to the monetary and prior review thresholds for procurements in this Act as may from time to time be determined by the Council". PPA's definition of "monetary threshold": "Monetary Threshold" means the value limit in Naira set by the Bureau outside of which an approving authority may not award a procurement contract": ${ }^{78}$ clearly indicates that there are approving authorities other than PTB and MTB, which is left to the discretion of the Federal Government to establish. If it is only the PTB and the MTB that are the exclusive approving authorities, the PPA would not refer to contracts of certain monetary threshold above which they cannot award or approve; for who will then award these contracts if no other approving authority is envisaged. Absurdity

\footnotetext{
${ }^{75}$ See FGN, 2009.

${ }^{76}$ CFRN S 144(5).

${ }_{78}^{7}$ FHC Abuja 26-10-2008 suit no ID/71c/2008.

${ }^{78}$ Section 60 (emphasis added). See also "threshold", and "approving authority" under s 60.
} 
will result if it is taken that only PTB and MTB are the approving authorities for contracts.

Whether the FEC decides to be involved in approving or awarding contracts or to abstain, the administration is held responsible for the contracts awarded and their execution within its term. ${ }^{79}$

\section{More powerful than the FEC}

Having misconstrued the NCPP as the ultimate contract approval authority, the former presidential spokesman, Dr Abati, had opined that the NCPP is more powerful than the FEC; citing it as a reason for the Federal Government's refusal to inaugurate the Council. ${ }^{80}$ This opinion is flawed because it is based on a faulty premise, as discussed in 421 above. Besides this, generally the Council cannot be viewed as more powerful than the FEC. First, the FEC is the highest federal executive decision-making body, headed by the President, according to the Nigerian Constitution. ${ }^{81}$ Secondly, the Chairman of the Council and the Attorney General are members of FEC and answerable to it. In addition, the four other permanent members are government officials directly answerable to the President and by extension the FEC. Thirdly, all members of the Council are appointees of the President; and they can be removed by the President at will. ${ }^{82}$ Thus, the NCPP as established by the PPA is subordinate to the FEC in status; and the Council's membership and by extension its powers are subject to the influence of the President (and by extension the FEC).

\section{Controls the BPP}

It has been stated that:

\footnotetext{
${ }^{79}$ For an illustration of the fact that the head of a government and his administration bear the responsibility for government contracts awarded in the administration, whether or not he was directly involved, see the following examples that relate to the United States of America (considering that reference was made, in Suleiman, 2013 to the USA in attempting to argue against FEC's involvement in approving certain contracts): Ivory, 2013; Perley, 2010; Capaccio, 2010. Capaccio, T., 2010.

${ }^{80}$ Citizen Confidential, 2012; Attah, 2012.

${ }^{81}$ See generally section 144 .

82 The PPA does not provide special procedures for their removal; thus, they are subject to the Interpretation Act s 11 that vests on an appointer the power to remove an appointee.
} 
"[T] he NCPP exerts control over the administration of BPP to ensure that the objectives of the Act are not defeated. It gives directives for implementation to the BPP to ensure that it does not depart from the fundamental principles for procurement." ${ }^{83}$

The statement did not delimit the extent of control or directives that the Council can respectively exert or give to the BPP. This may give the erroneous impression that the Council has direct control over the day-to-day administration of the BPP and that the BPP takes instructions on all matters from the Council. However, such wide control over the BPP is neither expressed nor contemplated by the law. It will negate the spirit of the law, which intends to confer substantial independence from procuring entities on the BPP- ${ }^{84}$ recall that four of the six government members of the NCPP are heads of procuring entities. ${ }^{85}$ The control that the Council will have over the BPP generally relates to exercising approval authority on certain actions or decisions of the BPP, where stipulated by the PPA. Even the BPP's staff regulations to be made by the Council would not be in the form of Council giving day-to-day directives to BPP. Rather, it will issue the regulations and the BPP will be allowed to operationalize it; akin to the relationship between the legislature and the executive.

The second statement in the quote above may have been based on section 2(f) of the PPA, which empowers the Council to: "give such other directives and perform such other functions as may be necessary to achieve the objectives of this Act" ${ }^{86}$ However, this provision does not support the aforementioned statement. The provision is the last paragraph of section 2; the preceding paragraphs enumerate the specific powers or functions of the Council. Thus paragraph $(f)$ is to be read in conjunction with and only within the context of the preceding paragraphs. This position is supported by the ejusdem generis rule, which holds that when a general word or phrase follows a list of specifics, the general word or phrase will be

\footnotetext{
${ }^{83}$ Osuntogun 2012:144.

${ }^{84}$ See World Bank, 2000. which reflects OECD-DAC/World Bank, 2006:24-25 sub-indicators 4(c) and (d). Both are to the effect that a procurement regulatory/normative body should have a degree of independence to enable it to carry out its responsibilities without interference, and be free from possible conflicts of interest. The Nigerian CPAR and by extension the MAPS, could be regarded as part of the sources of the PPA, since the Nigerian CPAR instigated and formed the foundation for the procurement reforms in Nigeria, including the enacting of the PPA. See Williams-Elegbe 2012:346.

${ }^{85}$ Two Ministers (Finance and Justice), Secretary to the Government of the Federation, and the Head of Service.

${ }^{86}$ Emphasis added.
} 
interpreted to include only items of the same class as those listed. ${ }^{87}$ Paragraph (f) could be viewed as a clause expressing the incident power of NCPP. Incident power is "[a] power that, although not expressly granted, must exist because it is necessary to the accomplishment of an express power". ${ }^{88}$ The foregoing leads inevitably to the conclusion that the non-specific power in paragraph (f) of section 2 is intended to be used only for achieving the Council's explicit functions contained in the preceding paragraphs. For example, for the purpose of carrying out its function of receiving and considering for approval the audited account of the BPP, the Council would be able to give directive to the BPP to forward its audited account; for the purpose of approving new procurement policies (especially if contentious), the Council could undertake incidental functions such as conducting a public hearing or receiving and considering memoranda from the public on the subject-matter.

Generally, failing to appropriately delimit the Council's apparent omnibus powers in section $2(\mathfrak{f})$ will result in absurdity unintended by the PPA. Since the provision did not specify the person or organisation to which the NCPP's directives shall be to, the power will not only be regarded as exercisable in relation to the BPP, but also exercisable in every procurement matter. To that extent, the Council could rely on the provision to procure for any government entity, contrary to the intendment of the Act. In the same vein, the provision may be construed, absurdly though, as given the Council the power to give directives to anybody, including the President.

As hinted above under this section, the misconceptions on the status and functions of the NCPP have contributed to the Federal Government's unwillingness to constitute the body. This has implications for the Nigeria's procurement system. The holding of the court in Cupero case that the Council is already statutorily established does not obviate this; for as seen in 411 above, there is a distinction between establishing the body and constituting it to undertake its functions.

\footnotetext{
${ }^{87}$ See Thomson Reuters 2009:594 "ejusdem generis"; also Attorney-General v Brown (1920) 1 KB 773 797; Jammal Steel Structures Ltd v A.C.B Ltd [1973] NSCC 619; Attorney-General of Cross River State $v$ Esin [1991] 6 NWLR (Pt. 197) 365.

${ }^{88}$ Thomson Reuters, 2009:1288 "incident power". See also Interpretation Act s 10(2).
} 


\section{Implications of not constituting the NCPP}

It suffices to say that without constituting the NCPP, its numerous functions shall be left unperformed or probably performed illegally by another office. All the functions of the NCPP that relate to its approving of actions or decisions of the BPP or other authorities, have been left unperformed, notwithstanding that these bodies involved have continued to undertake the related decisions and actions. Without the NCPP's approval as required by the law, the related decisions and actions lack validity (especially considering that the Council's functions are qualified by imperative words "shall"). ${ }^{89}$ However, what is temporary sustaining the system is that such decisions and actions taken by BPP and other authorities may be deemed as valid until declared invalid by the court; as there is a rebuttable presumption that administrative acts are valid, based on the maxim: omnia praesumuntur rite esse acta. ${ }^{90}$ The NCPP's functions that do not relate to approvals, such as: appointment of BPP's principal officers and employees, making BPP's staff regulations: ${ }^{91}$ have been performed by other authorities illegally. These clearly violate the law and could thus be invalidated upon review, for being ultra vires. ${ }^{92}$

The above identified illegality has opened the door to avoidable public interest litigations. For example, the Centre for Social Justice, a registered non-governmental organisation involved in promoting compliance with laws on social justice and accountability, sued the Nigerian President at the Federal Court to compel him to constitute the Council. The High Court ruled against the organisation and it proceeded on appeal. ${ }^{93}$ Even though such litigations may hardly be successful in

\footnotetext{
${ }^{89}$ Agricultural, Horticultural and Forestry Industry Training Board v. Aylesbury Mushroom Ltd [1972] 1 All ER 280; Bates v. Lord Hailsham [1972] I.W.L.R. 1373; Popoola v Adeyemo [1992] 3 NSCC 46. ${ }^{90}$ All things are presumed to have been done rightly (It means that if something is proved to have been done, it may be presumed to have been done regularly). See Dan Sale v Board of Customs and Excise 1966 NNLR 15; Ogbuanyinya v Okudo No 1 (1990) 4 NWLR (Part 46) 551 570; Akujinwa v Nwaonuma (1998) 13 NWLR (Pt.583) 632. See also Wade \& Forsyth 1994:333; De Smith et al 1995:15-85.

${ }^{91}$ However, subject to PPA s 10(2) that provides that any instrument relating to the conditions of service of officers in the civil service of the Federation shall apply until such regulations are made. ${ }_{92}$ Federal Minister of Internal Affairs v Shugaba Abdulrahaman Darma(CA) [1982] 1 FNLR 200; Otu Edet $v$ Chief of Air Staff and Attorney-General of the Federation [1994] 2 NWLR (Pt 324) 41.

${ }^{93}$ CSJ, 2013-2015.
} 
Nigeria, owing to the hurdle of locus standi, ${ }^{94}$ such cases demonstrate the public discontent with the current state of affairs concerning the Council.

The refusal to constitute the Council has set the Presidency on collision course with the National Assembly since the inception of the PPA to date. The publicised deliberate non-compliance of the executive with an existing law could in the opinion of the National Assembly constitute a gross misconduct which warrants invoking certain punitive measures against the executive. ${ }^{95}$

In addition, the refusal impugns the commitment of the Federal Government to the integrity of the procurement system, considering that the action frustrates the regulatory functions that the law intends the Council to perform. Not constituting the Council may suggest that the government is not keen or sincere about following through with its touted legal and practical reforms in the procurement system. This may reduce support by its international development partners in this regard.

There is a domino effect of the refusal to constitute the NCPP on the states. Most states model their public procurement laws after that of the Federal Government. The states where the procurement laws have established procurement regulatory bodies similar to the NCPP have also followed the example of the Federal Government in refusing to constitute such bodies. ${ }^{96}$

Apart from the illegality of not constituting the NCPP, the situation denies the system of numerous benefits inherent in the functions of the body. For example, the intended checks on BPP's regulatory and procurement operations are lost; ${ }^{97}$ the direct participation of CSOs in procurement regulatory activities through their

\footnotetext{
${ }^{94}$ Elendu v Ekwoaba (1995) 3 NWLR (Pt.386) 704 750-751:"[T]he implication of the term locus standi is very clear. It literally means a "place to stand" hence a standing to sue. In law, it denotes the legal capacity to institute proceedings in a court of law. In Nigeria, it is a constitutional requirement to enable a person to maintain an action and is limited to the prosecution of matters relating to the civil right and obligations of the plaintiffs be that plaintiff a person or persons, government or authority or any other juristic person .... To entitle a person to invoke judicial power, he must show that either his personal interest will immediately be or has been adversely affected by the action or that he has sustained or is in immediate danger of sustaining an injury to himself and which interest or injury is over and above that of the general public. What constitutes a legal right, sufficient special interest or interest adversely affected will, of course, depend on the facts of each case." See also Adesanya $v$ President of Nigeria (1981) 5 SC. 112 - 191, (1981) 2 NCLR 358.

${ }^{95}$ See $\mathrm{s} 143$ of the Constitution; and by virtue of $\mathrm{s} 80$ of the Constitution the National Assembly can withhold approval of budget meant for public procurement regulatory functions.

${ }_{96}$ To mention a few: Anambra, Cross River, Enugu, Jigawa, and Niger.

${ }^{97}$ The BPP has a fund and can award contracts towards the discharge of its functions; in such limited instances it stands as a procuring entity.
} 
Council's membership is lost; also the expertise that the members from professional organisations would have brought directly into procurement policy-making and practices through the NCPP is lost.

\section{Benefits of constituting the NCCP}

It suffices to generally capture the benefits of constituting the Council by stating that such will reverse the negative effects of not constituting it. However, it is apposite to emphasis a few specific benefits. First, the Council's function will enrich public procurement regulatory functions of the BPP; as the Council will specialise in considering and approving relevant propositions and actions, while the BPP will specialise in operationalizing them. This will make BPP more focused, accountable and responsive to its regulatory functions over the whole system. Secondly, CSOs' direct or indirect involvement in the constituted NCPP will enhance their sense of responsibility and support towards a public procurement system known for its integrity, where deviations are not tolerated. ${ }^{98}$ Thirdly, it will result in the certainty and security of Nigeria's procurement policies and regulations, which are currently under the threat of invalidation for not being approved by the Council. Fourthly, the states will follow the good example set by the Federal Government to pursue full procurement reform implementation, including constituting their own equivalent of the NCPP, where provided.

\section{Conclusion}

The failure to constitute the Council is indicative of a dichotomy between procurement regulations and their implementation or enforcement in Nigeria. It is noteworthy that the Federal Government had in recent past attempted to amend the PPA to alter the status and functions of the NCPP. ${ }^{99}$ This was also clearly owing to the misconceptions about the Council's status and functions. Even though it may not be advisable to undertake the amendment of the PPA in this regard, considering the foregoing discourse, it is more tenable for the executive to send a bill to the National Assembly to amend the PPA than refusing to comply with an existing law. ${ }^{100}$ The

\footnotetext{
${ }^{98}$ See OECD-DAC/World Bank, 2006:45.

${ }^{99}$ Citizen Confidential, 2012; Attah, 2012.

100 The Federal Government may present reasons (other than those addressed above, identified as rooted in misconceptions) for seeking to amend the PPA to alter the status and functions of the
} 
Federal Government could also settle its uncertainties about the intendments of the law on the Council's status and functions by seeking judicial interpretation of the related sections of the PPA.

If the new President inaugurates the Council, how it will operate and how other authorities and persons will relate to it will depend on the extent of understanding of its status, functions and the issues addressed in this paper. Thus, this discourse will continue to be relevant even when the NCPP is hopefully inaugurated.

NCPP, or even to scrap it. It may argue that it wishes to scrap the Council in accordance with the new administration's policy of running a lean government and reducing the cost of governance; that it wishes to transfer the Council's functions to an already existing administrative structure, such as the Federal Executive Council. It will then be left for the National Assembly to decide whether to amend the PPA, and to what extent. 


\section{Bibliography}

Adesanya v President of Nigeria (1981) 5 SC. 112 - 191, (1981) 2 NCLR 358.

AfDB, OECD \& UNDP, 2014. African Economic Outlook: Nigeria 2014. [pdf] Abidjan:

AfDB. Available at:

<http://www.africaneconomicoutlook.org/fileadmin/uploads/aeo/2014/PDF/CN_Long_ EN/Nigeria_EN.pdf> [Accessed 04 September 2015].

Agricultural, Horticultural and Forestry Industry Training Board v. Aylesbury Mushroom Ltd [1972] 1 All ER 280.

Akalugo, A., 2011. How Nigerian Leaders Failed to Implement the Public Procurement Act 2007: A Case of Non-Constitution of the National Council on Public Procurement (1). NewsDiary, [online] 11 July. Available at:

<http://newsdiaryonline.com/ncpp.htm> [Accessed 06 June 2015].

Akujinwa v Nwaonuma (1998) 13 NWLR (Pt.583) 632.

Alliance for Democracy $(A D)$ v Plateau State Independent Electoral Commission [2004] 10 NWLR [Pt 880] 19.

Arrowsmith, S. 1992. Enforcing the EC Public Procurement Rules: the Remedies System in England and Wales. Public Procurement Law Review 2:92-118.

Attah, M. B., 2012. Abati's Blunder: FEC, Procurement Council and Contract Approval. Newsdiaryonline, [online] 27 February. Available at:

$<$ http://newsdiaryonline.com/abatis-blunderfec-procurement-council-and-contractapproval-by-mohammed-bougei-attah/> [Accessed 28 May 2015].

Attorney-General v Brown (1920) 1 KB 773 797; Jammal Steel Structures Ltd v A.C.B Ltd [1973] NSCC 619.

Attorney-General of Cross River State v Esin [1991] 6 NWLR (Pt. 197) 365.

Bates v. Lord Hailsham [1972] I.W.L.R. 1373. 
BBC, 2014. Nigeria becomes Africa's biggest economy. $B B C$, [online] 6 April. Available at: <http://www.bbc.com/news/business-26913497> [Accessed 16 April 2015].

Braithwaite v Grassroots Democratic Movement (1998) 7 NWLR (Pt 557) 307.

Capaccio, T., 2010. Obama administration approves No-Bid Halliburton Contract... I guess the evil Cheney wasn't so evil after all? Liveleak, [online] 06 July. Available at: <http://www.liveleak.com/view?i=2e1_1273440915> [Accessed 06 June 2015].

CBN v System Application Products Nigeria Limited (2005) 3 NWLR (Pt. 911) 152.

Centre for Social Justice (CSJ), 2013-2015.Public Procurement. CSJ, [online]. Available at: < http://csj-ng.org/programmes/public-finance/public-procurement/> [Accessed 04 June 2015].

Channels Television, 2012. It is illegal for FEC to be awarding contracts... Senate. Channels [online] 01 March. Available at: <http://www.channelstv.com/2012/03/01/itis-illegal-for-fec-to-be-awarding-contracts\%E2\%80\%A6senate/> [Accessed 01 May 2015].

Citizen Confidential, 2012. Deepening Violations of the Public Procurement Act (Media Statement by the National Procurement Watch Platform). Citizen Confidential, [online] 27 February. Available at: $<$ http://citizenconfidential.com/deepening-violations-of-the-public-procurement-act/> [Accessed 20 December 2014].

Constitution of the Federal Republic of Nigeria 1999.

Cupero Nigeria Limited v Federal Ministry of Water Resources FHC Abuja 12-6-2012 suit no FHC/Abj/CS/867/11.

Dailyindependent, 2014. Quantity surveying body calls for public procurement council. Dailyindependent, [online] 14 July. Available at:

$<$ http://dailyindependentnig.com/2014/07/quantity-surveying-body-calls-publicprocurement-council/> [Accessed 16 April 2015].

Dan Sale v Board of Customs and Excise 1966 NNLR 15. 
De Smith, S.A., Woolf, H. \& Jowell, J. 1995. Judicial Review of Administrative Action. $5^{\text {th }}$ ed. London : Sweet \& Maxwell.

Elendu v Ekwoaba (1995) 3 NWLR (Pt.386) 704.

Essia, U \& Yearoo, A. 2009. Strengthening Civil Society Organizations/Government Partnership in Nigeria. International NGO Journal 4(9):368-374. Available at: <http://www.academicjournals.org/article/article1381501695_Essia\%20and\%20Year oo.pdf > [06 September 2015].

Federal Government of Nigeria (FGN), 2009. Implementation of approved revised Thresholds for Service-wide Application and Special Application to the Federal Ministry of Petroleum for Expenditure related to the Nigerian National Petroleum Corporation (NNPC), Procurement Methods and Thresholds of Application and the Composition of Tenders Boards (circular SGF/OP/I/S.3/VIII/57 of 11/3/2009). Abuja: FGN.

Federal Inland Revenue Service (Establishment) Act 2007 (Nigeria).

Federal Republic of Nigeria v Olabode George FHC Abuja 26-10-2008 suit no ID/71c/2008.

Federal Minister of Internal Affairs v Shugaba Abdulrahaman Darma (CA) [1982] 1 FNLR 200.

Finance (Control and Management) Act 1958 Cap F26 LFN 2004 (Nigeria).

Fiscal Responsibility Act 2007 (Nigeria).

Harvela Investments Ltd v Royal Trust of Canada (CI) Ltd [1986] AC 207.

Ikelegbe, A. 2013. State, Civil Society and Sustainable Development in Nigeria. CPED Monograph Series 7:1-69.

Infrastructure Concession Regulatory Commission (Establishment, etc) Act 2005 (Nigeria).

Interpretation Act CAP I23 LFN 2004. 
Ivory, D., 2013. No-bid U.S. government contracts jump 9 percent, despite push for competition. The Washington Post, [online] 17 March. Available at:

$<$ http://www.washingtonpost.com/business/economy/no-bid-us-governmentcontracts-jump-9-percent-despite-push-for-competition/2013/03/17/9f6708fc-8da011e2-b63f-f53fb9f2fcb4_story.html> [Accessed 06 June 2015].

Jammal Steel Structures Ltd v A.C.B Ltd [1973] NSCC 619.

Legal Education (Consolidation, Etc.) Act Cap L10 LFN 2004 (Nigeria).

Marshall, R. C., Muerer, M.J. \& Richard J-F. 1991. The Private Attorney General Meets Public Contract Law: Procurement Oversight by Protest. Hofstra Law Review 20:1-72.

National Environmental Standards and Regulations Enforcement Agency (Establishment) Act 2007 (Nigeria).

Newsdiaryonline, 2011. Constitute National Council on Public Procurement Now! New Procurement Anti-Corruption Group tells FG. Newsdiaryonline, [online] 26 February. Available at: <http://newsdiaryonline.com/council_now.htm> [Accessed 16 April 2015].

Nigeriannewsservice, 2009. Yar'adua's FEC has become a tender's board-Rep Tuggar. Nigeriannewsservice, [online] 06 September. Available at: <http://www.nigeriannewsservice.com/yaraduas-fec-has-become-a-tenders-boardrep-tuggar/> [Accessed 04 June 2015].

Nigerian Senate, 2012. Order Paper (No 139). Abuja: National Assembly.

OECD-DAC/World Bank, 2006. Methodology for Assessment of National Procurement Systems (MAPS). [pdf] Paris: OECD. Available at: $<$ http://www.oecd.org/dac/effectiveness/45454394.pdf> [Accessed 05 September 2015].

Ogbuanyinya v Okudo No 1 (1990) 4 NWLR (Part 46) 551570.

Onyekpere, E., 2013. Revisiting the National Council on Public Procurement. Punch Newspaper online, [online] 29 July. Available at: 
$<$ http://www.punchng.com/opinion/revisiting-the-national-council-on-publicprocurement/> [Accessed 04 June 2015].

Osuntogun, J. 2012. Procurement Law in Nigeria: Challenge for Attainment of its Objectives. Public Procurement Law Review 4:139-152.

Otu Edet $v$ Chief of Air Staff and Attorney-General of the Federation [1994] 2 NWLR (Pt 324) 41.

Perley, F., 2010. Obama's mounting hypocrisy. The Washington Times, [online] 13 May. Available at: <http://www.washingtontimes.com/news/2010/may/13/obamasmounting-hypocrisy/> [Accessed 06-06-2015].

Popoola v Adeyemo [1992] 3 NSCC 46.

Procurement Monitor, 2011. BPP operating illegally -Reps Give Jonathan 21 days ultimatum. Procurement Monitor Blog, [online] 30 November. Available at: $<$ http://www.procurementmonitor.org/blog/2011/11/30/bpp-operating-illegally-reps\%E2\%80\%A2give-jonathan-21-days-ultimatum/> [Accessed 10 June 2015].

Public Enterprises (Privatisation and Commercialisation) Act 1999 (Nigeria).

Public Procurement Act 2007 (Nigeria).

Public Procurement and Disposal Act 2005 (Kenya).

Quinot, G. 2012. A Comparative Perspective on Supplier Remedies in African Public Procurement Systems. In Quinot G. \& Arrowsmith, S. (Eds.). Public Procurement Regulation in Africa. Cambridge: Cambridge University Press.

Suleiman, 2013. Jonathan as President and Contractor-in-Chief. Nigerianstalk, [online] 17 June. Available at: <http://nigerianstalk.org/2013/06/17/jonathan-aspresident-and-contractor-in-chief/> [accessed 21 May 2015].

The Economist, 2014. Nigeria: Africa's new Number One. The Economist, [online] 12 April. Available at: <http://www.economist.com/news/leaders/21600685-nigeriassuddenly-supersized-economy-indeed-wonder-so-are-its-still-huge> [Accessed 16 April 2015]. 
Thisdaylive, 2012. Concern over Executive Recklessness. Thisdaylive, [online] 04 March. Available at: <http://www.thisdaylive.com/articles/concern-over-executiverecklessness/110584/> [Accessed 20 December 2014].

Thomson Reuters, 2009. Black's Law Dictionary 9th ed. Minnesota: Thomson Reuters Business.

Udeh, K.T. \& Ahmadu, M. 2012. Regulatory Framework for Public Procurement in Nigeria. In Quinot G. \& Arrowsmith, S. (Eds.). Public Procurement Regulation in Africa. Cambridge: Cambridge University Press.

UNCITRAL Model Law on Procurement of Goods, Construction and Services 1994.

UNCITRAL Model Law on Public Procurement 2011.

Wade, H.W.R. \& Forsyth, C.F. 1994. Administrative Law. Oxford, UK: Clarendon Press.

Williams-Elegbe, S. 2012. The Reform and Regulation of Public Procurement in Nigeria. Public Contract Law Journal 41(2):339-366.

World Bank, 2000. Nigeria Country Procurement Assessment Report(CPAR) vol l. [pdf] Washington, DC: World Bank. Available at: $<$ http://documents.worldbank.org/curated/en/2000/06/1121258/nigeria-countryprocurement-assessment-report-cpa> [Accessed 05 September 2015].

World Bank, 2005. Social Accountability Sourcebook chapter 2- Social Accountability: What Does it Mean for the World Bank? [pdf] Washington, DC: World Bank. Available at:

<http://www.worldbank.org/socialaccountability_sourcebook/PrintVersions/Conceptu al\%2006.22.07.pdf> [Accessed 05 September 2015].

Zhang, X. 2007. Supplier Review as a Mechanism for Securing Compliance with Government Public Procurement Rules: a Critical Perspective. Public Procurement Law Review 16:325- 351. 